\title{
HISTOLOGICAL STUDY ON THE PANCREATIC $\beta$-CELL NUMBER OF INDIGENOUS CHICKS IN FIRST CROSSBRED $\left(\mathrm{F}_{1}\right)$
}

\author{
H.T.S.S.G. Saragih and B. S.Daryono \\ Faculty of Biology, Gadjah Mada University, \\ Jl.Teknika Selatan,Sekip Utara, Yogyakarta, 55281 \\ Corresponding E-mail: hendrysaragih@yahoo.com
}

Received June 8, 2009; Accepted July 26, 2010

\begin{abstract}
The objective of this study was to evaluate the total pancreatic $\beta$-cell number of chicks in first crossbred $\left(\mathrm{F}_{1}\right)$ with potential as broiler. The total number of twenty day-old male chicks consisted of DOCs Cobb 500 broiler line as a control group and those of Pelung and the crossbred of Pelung and Cemani chicks with the average body weight of 30 gram as materials. They were divided into four groups, in which each group has 5 male DOC's. Group 1 was DOCs from parent of Cobb 500 broiler as the control; Group 2 was DOCs from parent of Pelung; Group 3 was crossbred DOCs from male parent Cemani line and female parent Pelung line; and Group 4 was crossbred DOCs taken from male parent of Pelung and female parent of Cemani. Chick body weight of each group was measured at $7^{\text {th }}$ week. Histological process was carried out on five DOCs of each group previously raised until seven weeks old and at the end of experiment all chicks were euthanized for pancreatic organs, particularly tissue samples of pancreas, made as histological preparates. Data from the histological probe on total pancreatic $\beta$-cell number was statistically analyzed using the ANOVA of One Way Classification, and then followed by the LSD-test. Result of the study showed that average body weights of DOCs in the control group of Cobb $500(2770 \pm 58.31)$ significantly higher $(\mathrm{P}<0.05)$ compared to the groups of 2,3 , and $4(652.4 \pm 32.77,570.4 \pm 14.45$, and $628 \pm 37.2 \mathrm{~g}$, respectively). Total pancreatic $\beta$-cell number in the control group of Cobb 500 broiler chicks $\left(2.76 \times 10^{6} \pm 0.20 \times 10^{6}\right)$ significantly higher compared to the groups of 2,3 , and $4\left(1.93 \times 10^{6} \pm 0.34 \times 10^{6}, 1.64 \times 10^{6} \pm 0.30 \times 10^{6}\right.$, and $1.71 \times 10^{6} \pm 0.19 \times 10^{6}$, respectively). The results of this study revealed that total pancreatic $\beta$-cell number can be used as an indicator of the growth and development of chick.
\end{abstract}

Keywords: Chicks of Pelung and Cemani line, Pancreatic $\beta$-cell

\section{INTRODUCTION}

The improvement of indigenous chicks is an investment for national germplasm resource in the future. In a short-term, the activity will be profitable, while in a long-term the benefit is particularly in a preservation of broiler-typical local chicks. In 2004 population of local chicks reached 271.8 million and from 2003 to 2005 the mortality reached 10.45 million resulted from disease (Bappenas, 2005). At the same time, market demand on the livestock commodity of indigenous chicks always increased, for example, the Province of DKI Jakarta produced 240 ton meat annually or equaled to 240 thousand of chicks (Badan Penelitian dan Pengembangan Pertanian, 1999).

At present, the germplasm management of indigenous chick in Indonesia is mostly handled by government at a central level, while the working units of managing the local chicks' germplasm at a level of the technical department of agriculture in regency and community was not sufficient (Iskandar, 2006).

The management of indigenous chicks that has been carried out in the area of West Java Province is that of indigenous chicks, is called as Pelung. The variety is mostly used by community for a contest of crowing voice and appearance of male chicks (Nataamijaya, 2005).

The existence of the local chicks in many regions throughout Indonesia was reported, but the efforts of preservation were not so obvious yet. Variety of local chicks scattering in some regions included chick of strain Balenggek with typical feature of laddering crowing voice, Merawang, Nunukan known as a red chick of dual-purpose type, Cemani known as a superior 
egg-layer local chick, and Ciparage known as a contested chick, which was extinct (Iskandar, 2006).

The capacity of local broiler is not adequate compared to that of non-local ones where the former takes approximately 16 weeks while the latter only five weeks to reach the body weight of 1500 gram. Obstacles for the improvement of genetic quality in indigenous chicks of Indonesia with the great potential as broiler include unobvious process of crossbreed and the unavailability of studies on the identification of local broiler potentials.

Pancreatic $\beta$-cell is a cellular part located in pancreatic islets of langerhans. The islet is an endocrine part of pancreatic tissues in which there are three types of cell, i.e. A cell (Alpha), B cell (Beta), and D cell (Delta). The beta cell number in islets is more than others and located in the mid of islets, and that of $\mathrm{A}$ and $\mathrm{D}$ cells is lesser and located in islet periphery. The beta cell serves as producing insulin enzyme that work on cell membrane (mainly in liver and muscles) and the insulin will facilitate the transport of glucose into cell, so the content of blood glucose decreases (Leeson et al., 1996). The insulin hormone is known as playing a role in the partition of substrate into developing body cells and when the catabolism process of body occurs. Insulin also serves as to regulating the concentration of amino acids. The high level of insulin hormone in body can be made as an indicator of growth and development of chick body ( $\mathrm{Lu}$ et al., 2007). It is well-known that the pancreatic $\beta$-cell in each species has difference in number. The pancreatic $\beta$-cell number can be used to describe difference in age (Bock et al., 1999).

As the effort of identifying such potential, this histological study aimed at evaluating the pancreatic $\beta$-cell number of crossbred local chicks.

\section{MATERIALS AND METHOD}

\section{Materials}

Solutions, including bouin, ethanol, toluol, paraffin, xylene, potassium permanganate, sodium bisulfate, chromium hematoxylin, phloxine $\mathrm{B}$, and phospotungstic acid (E.Merck, Germany), were used to make histological preparates and Gomori solution for special staining of pancreatic $\beta$-cell. Body weight scale, object glass for histological process, hot plate, rotary microtome and microscope were used.

Total number of twenty day-old male chicks of Cobb 500 strain (as a control group), Pelung strain and the first crossbred $\left(\mathrm{F}_{1}\right)$ of Pelung and Cemani with average weight of 30 gram were used in the study. Chicks were raised with a semiintensive hen house system. All chicks were normally fed by the type of BR 1 (P.T. Cargill Indonesia) and drinking water ad libitum.

Chicks were divided into four groups and each group consisted of five day-old male chicks. Group 1 was a control group of DOCs from parent Cobb 500 (broiler) line; Group 2 was from parent Pelung; Group 3 was DOCs crossbred from male parent Cemani and female parent Pelung; Group 4 was DOCs crossbred from male parent Pelung (potential for broiler) and female parent Cemani (potential for layer). Body weight of five DOCs in each group was measured at $7^{\text {th }}$ weeks and then terminated for pancreatic organ. The calculation of pancreatic $\beta$-cell number was done using the Gomori staining.

\section{Histological sample preparation}

After being separated, pancreatic tissue was then cut into small pieces of tissues with $3 \times 3$ $\mathrm{mm}$ in size and the fixation process was run using bouin solution. The further process was dehydration using alcohol ranging from $70 \%$ to absolute alcohol. Clearing process was done by using toluol compound. Furthermore, tissue sample of pancreas obtained through paraffin infiltration process was then embedded by a paraffin wax through a rapid cooling process. The web of paraffin cast was cut of $4 \mu \mathrm{m}$ using rotary microtome and attached on object glass. The processes of deparaffinization and rehydration were done using xylene and alcohol solutions (McManus and Mowry, 1960).

\section{Calculation of pancreatic $\beta$-cell number}

\section{The first-stage fractinator}

After the fixation process, each pancreas was cut into 22 pieces with the same size $(3 \times 3 \mathrm{~mm})$. Twenty pieces of pancreas were then ordered in accordance with initial forms and then each of five pieces were sampled (using the Regular Randomized Sampling System) by taking random figures between 1 and 5, for example, from third piece. The sampling started from $3,8,13$, and so 
forth and was begun from the left to the right of pancreatic pieces. Furthermore, the first-stage fractinator was symbolized as $\mathrm{f}_{1}=1 / 5$ (Bock et al., 1999).

\section{The second-stage fractinator}

The piecess obtained at the first stage were then infiltrated into paraffin, and the organ was then embedded. In the sectioning process, the cutting of pancreas was done with $4 \mu \mathrm{m}$ in thickness by using the rotary microtome. The cutting at the second stage was done each 200 piecess using the regular randomized sampling system by taking random figures between 1 and 200 , for example, sampling from $125^{\text {th }}$ piece. The sampling started from $125^{\text {th }}$ piece made as sample as follows: $125^{\text {th }}$ and $126^{\text {th }}, 325^{\text {th }}$ and $326^{\text {th }}$, and $525^{\text {th }}$ and $526^{\text {th }}$ pieces. The $125^{\text {th }}, 325^{\text {th }}$, and $525^{\text {th }}$ pieces were called as primary sections, while the $126^{\text {th }}, 326^{\text {th }}$, and $526^{\text {th }}$ were called as a reference section. Furthermore, the second-stage fractinator was symbolized as $\mathrm{f}_{2}=1 / 200$ (Bock et al., 1999).

\section{The third stage fractinator The Gomori staining}

After the pieces of tissue samples of pancreas were attached on object glass and the process of deparaffinization and rehydration were done, the tissue samples of pancreas were then stained by using the Gomori special staining. The preparates were deparaffinized using xylol solution, the process of rehydration was then done using ladder alcohol to aquades. The next step was that the preparates were colored by potasium permanganate solution which were then cleared by using sodium bisulfate solution until the pieces of pancreas seemed clear. The preparates were washed in the flowing water for two minutes, then colored using chromium hematoxylin solution for 10 minutes. The next stage was that the preparates were washed in the flowing water for 10 minutes, then colored using phloxine $B$ solution for 5 minutes. The results of the painting were then washed in aquades and phospotungstic acid solution for one minutes. Furthermore, the preparates were washed in the flowing water for five minutes. To distinguish between beta cell (blue in color with the Gomori painting) and alpha cell atau delta and blood cells (red in color) alcohols $96 \%$ and $80 \%$ were used. The preparates were eventually immersed into absolute and xylol solutions, then the object glasses were covered by using the Canada balsam (McManus and Mowry, 1960). After the pieces were seen under microscope with magnification of 10 X 100, the pieces of primary sections were made as references of seeing the pancreatic $\beta$-cell in reference sections. The technique of collecting the pancreatic sel $\beta$ under microscope was to divide the area of Langerhans islands into the same five sections, after of which the calculation was just conducted in one section. The third-stage fractinator was called as $\mathrm{f}_{3}=1 / 6$ (Bock et al., 1999). The technique of calculating the pancreatic $\beta$-cell number of chicks at $7^{\text {th }}$ week can be seen at Figure 1

\section{The calculation of total pancreas b-cell number}

Total pancreas $\beta$-cell number obtained in the third stage fractinator was then calculated using the following formulation:

$\left(1 / f_{1}\right) \times\left(1 / f_{2}\right) \times\left(1 / f_{3}\right) \times$ total $\beta$-cell number per chick (Bock et al., 1999)

\section{Statistical analysis}

Result of the study for genetic parameter was analysed by using analysis of variance (ANOVA) of One Way Classification. The pancreatic $\beta$-cell number data were analysed with a 1-way ANOVA. When significant, the differences between the treatment means tested using LSDtest $(\mathrm{P}<0.05)$. All statistical analyses used SPSS 13.0 software (SPSS Science, 2006).

\section{RESULT AND DISCUSSION}

Results of the body weight measurement for the control group of Cobb 500 broiler chick and local chicks $\left(\mathrm{F}_{1}\right)$ can be seen in Table 1 . Outcomes of body weight (gram) in each group as follow: Group 1 was 2770 \pm 58.31 , Group 2 was 652.4 \pm 32.77 , Group 3 was $570.4 \pm 14.45$, and Group 4 was $628 \pm 37.2$. The result of the statistical analysis indicated that there was significant differences ( $>>0.05)$ between Group 1 and Groups 2, 3 and 4, meanwhile for the body weight of Groups 2, 3 and 4 there were no statistical differences. The difference in body weight of Group 1, i.e. Cobb 500 broiler chicks, and local chicks of Indonesia could be resulted from the regulating process of feed intake, and the absorption of nutrients for broiler was highly efficient compared with local chicks. In broiler, 


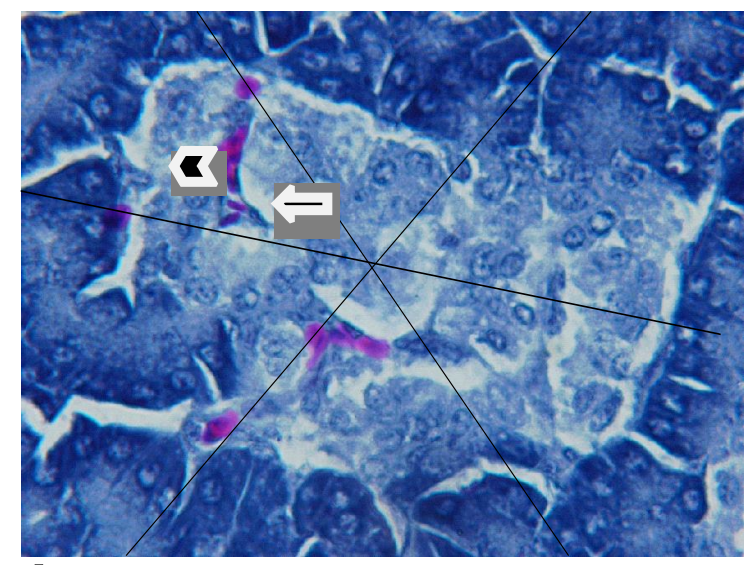

โอ

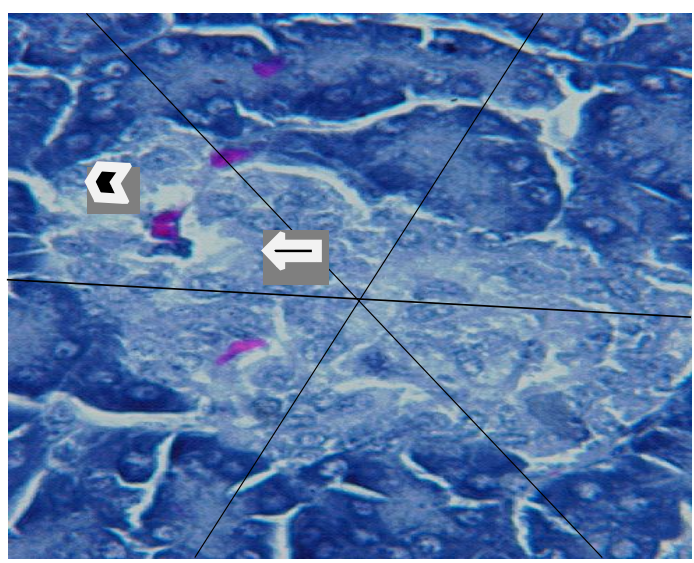

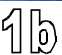

Figure 1. 1a. The primary section (stained by Gomori 10x100) and 1b. The reference section (stained by Gomori 10x100). Arrow indicates that the beta cell was calculated as they seemed in the reference section, and arrow head shows that the beta cell was not calculated since they did not seem in the reference section.

Table 1. Average Body Weight of Local Chicks (F1) at 7th Week

\begin{tabular}{|c|c|c|c|}
\hline No & Groups & $\mathrm{N}$ & Body weight (gram) \\
\hline 1 & 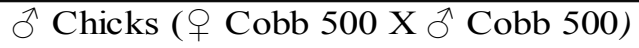 & 5 & $2770 \pm 58.31^{\mathrm{a}}$ \\
\hline 2 & $\widehat{\delta} \mathrm{F}_{1}$ (우 Pelung $\mathrm{X} \widehat{\delta}$ Pelung) & 5 & $652.4 \pm 32.77^{b}$ \\
\hline 3 & $\widehat{\delta} \mathrm{F}_{1}$ (우 Pelung $\mathrm{X} \delta$ Cemani) & 5 & $570.4 \pm 14.45^{b}$ \\
\hline 4 & $\lesssim \mathrm{F}_{1}$ ( $q$ Cemani $\mathrm{X} \lesssim$ Pelung) & 5 & $628.0 \pm 37.2^{\mathrm{b}}$ \\
\hline
\end{tabular}

Different superscript in same column indicates differ significantly $(\mathrm{P}<0.05)$

Table 2. Pancreatic $\beta$-cell Number in Local Chicks at $7^{\text {th }}$ Week

\begin{tabular}{|c|c|c|c|}
\hline No & Groups & $\mathrm{N}$ & $\begin{array}{c}\text { Total } \beta \text {-cell } \\
\text { number }(\mathrm{x} 106)\end{array}$ \\
\hline 1 &  & 5 & $2.76 \pm 0.20^{\mathrm{a}}$ \\
\hline 2 & $\lesssim \mathrm{F}_{1}$ ( $($ P Pelung $\mathrm{X} \circlearrowright$ Pelung) & 5 & $1.93 \pm 0.34^{\mathrm{b}}$ \\
\hline 3 & $\widehat{\delta} \mathrm{F}_{1}$ ( $q$ Pelung $\mathrm{X} \widehat{\partial}$ Cemani) & 5 & $1.64 \pm 0.30^{b}$ \\
\hline 4 & $\lesssim \mathrm{F}_{1}$ ( $q$ Cemani $\mathrm{X} \lesssim$ Pelung) & 5 & $1.71 \pm 0.19^{\mathrm{b}}$ \\
\hline
\end{tabular}

Different superscript in same column indicates differ significantly $(\mathrm{P}<0.05)$

the activity of tripsin enzyme and other protease enzymes as digestive enzymes occurred in the greatly high level of growth period. The intestinal absorption of amino acids, particularly lysin amino acid, in young broiler was very good. It is the absorption that caused the high value of digestion in broiler, particularly from 14 to 21 days old (Giachetto et al., 2003; Zuprizal, 2008).

Result of the calculation of pancreatic $\beta$-cell number in the control group of broiler chick and local chick of strain $F_{1}$ can be seen in Table 2 .
Pancreatic $\beta$-cell number in Group 1 was significantly different with that of Groups 2, 3, and 4. Pancreatic $\beta$-cell number in Group 1 was higher than that in local chick groups. It could be due to the fact that growth of broiler was more rapid so the pancreatic $\beta$-cell number was high and it can be known that pancreatic $\beta$-cell has a main function as biosynthesis place and meet the secretion of insulin hormone (Barr et al., 1997; Seufert, 2004). According to Lu et al. (2007) the 
insulin hormone serves as increasing the growth and development of chick body. Furthermore, the hormone status of breeders may be a key indicator to help predict the body composition (Sun et al., 2006). Based on the result of the study, it can be concluded that pancreatic $\beta$-cell number can be made as a reference of identifying the potentials of local chicks as broilers.

\section{CONCLUSION}

Pancreatic $\beta$-cell number in the Cobb 500 broiler chick was larger than that of local chicks. Pancreatic $\beta$-cell number could be made as an indicator of seeking the potential of local chicks as broilers.

\section{ACKNOWLEDGEMENT}

The author acknowledged to the Dean of Biology Faculty, Gadjah Mada University, for community service fund provided through a grant for the Faculty Research Management and Development Team (Tim Pengelola and Pengembangan Penelitian Fakultas-(TP3F) of 2007.

\section{REFERENCES}

Balai Penelitian dan Pengembangan Pertanian Instalasi Penelitian dan Pengkajian Teknologi Pertanian DKI Jakarta, 1999. Inseminasi buatan pada ayam buras. Dinas Pertanian, Jakarta

Bappenas Republik Indonesia. 2005. Rencana Strategis Nasional Pengendalian Flu Burung (Avian Influenza) dan Kesiapsiagaan Menghadapi Pandemi Influenza 2006-2008; hal.4

Barr, V.A., D. Malide, M.J. Zarnowski, S.I. Taylor, and S.W. Cushman. 1997. Insulin stimulates both leptin secretion and productin by rat white adipose tissue. Endocrinology. 138(10): 4463-4472
Bock, T., K.Svenstrup, B. Pakkenberg and K. Buschard. 1999. Unbiased estimation of total $\beta$-cell number and mean $\beta$-cell volume in rodent pancreas, APMIS 107:791-799

Giachetto, P.F., E.N. Guerreiro, J.A. Ferro, M.I.T. Ferro, R.L. Furlan and M. Macari. 2003. Performance and hormonal profile in broiler chickens fed with different energy levels during post restriction period, Pesq.agropec.bras., 38(6): 697-702

Iskandar, S. 2006. Pelestarian plasma nutfah ayam lokal domestik, Warta Penelitian dan Pengembangan Pertanian. 28(3):11-13

Leeson, R.C., T.S. Leeson. and A.A. Paparo. 1996. Buku Ajar Histology (Textbook of Histology). Edisi V. EGC. Jakarta

Lu, J.W., J.P. McMurtry and C.N. Coon. 2007. Developmental changes of plasma insulin, glucagon, insulin-like growth factors, thyroid hormones, and glucose concentrations in chick embryos and hatched chicks. Poult.Sci. 86:673-683

McManus, J.F.A. and R.W. Mowry. 1960. Staining Methods Histologie and Histochemical, Paul B. Hoeber, Inc. 8-52

Nataamijaya, A.G. 2005. Karakteristik Penampilan Pola Warna Bulu, Kulit, Sisik Kaki, dan Paruh Ayam Pelung di Garut dan Ayam Sentul di Ciamis. Buletin Plasma Nutfah.11(1):1

Seufert, J. 2004. Leptin effects on pancreatic beta cell gene expression and function, Diabetes. 53:152-158

SPSS 13.0. 2006. SPSS Science, SPSS Inc.,Chicago

Sun, J.M., M.P. Richards, R.W. Roserbrough, C.M. Ashwell, J.P. McMurtry and C.N. Coon. 2006. The relationship of body composition, feed intake, and metabolic hormones for broiler breeder females. Poult.Sci. 85:1173-1184

Zuprizal, 2008. Industri Pakan Ternak Unggas di Indonesia: Tinjauan Dari Penggunaan Makronutrien Protein Pakan. Pidato Pengukuhan Jabatan Guru Besar UGM. hal.15-16 